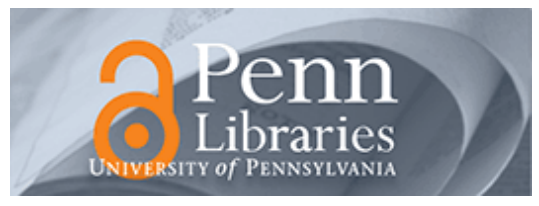

University of Pennsylvania

ScholarlyCommons

Marketing Papers

Wharton Faculty Research

March 1986

\title{
The value of formal planning for strategic decisions: reply
}

\author{
J. Scott Armstrong \\ University of Pennsylvania, armstrong@wharton.upenn.edu
}

Follow this and additional works at: https://repository.upenn.edu/marketing_papers

\section{Recommended Citation}

Armstrong, J. S. (1986). The value of formal planning for strategic decisions: reply. Retrieved from https://repository.upenn.edu/marketing_papers/23

Postprint version. Published in Strategic Management Journal, Volume 7, Number 2, March-April 1986, pages 183-185. The author has asserted his/her right to include this material in ScholarlyCommons@Penn.

Publisher URL: http://www3.interscience.wiley.com/cgi-bin/jhome/2144

This paper is posted at ScholarlyCommons. https://repository.upenn.edu/marketing_papers/23

For more information, please contact repository@pobox.upenn.edu. 


\title{
The value of formal planning for strategic decisions: reply
}

\author{
Abstract \\ In Armstrong (1982a), I examined alternative explanations to the empirical findings that supported the \\ use of formal planning. In considering the possibility that researcher bias might lead to such results, I \\ used Terpstra's (1981) evaluation scheme. Based on this test, poor methodology did not seem \\ responsible for the conclusions on the value of formal planning.

\section{Comments} \\ Postprint version. Published in Strategic Management Journal, Volume 7, Number 2, March-April 1986, \\ pages 183-185. The author has asserted his/her right to include this material in \\ ScholarlyCommons@Penn. \\ Publisher URL: http://www3.interscience.wiley.com/cgi-bin/jhome/2144
}


Published in Strategic Management Journal, 7, 1986, 183-185.

\title{
The Value of Formal Planning for Strategic Decisions: A Reply
}

\author{
J. Scott Armstrong \\ The Wharton School, University of Pennsylvania
}

In Armstrong (1982a), I examined alternative explanations to the empirical findings that supported the use of formal planning. In considering the possibility that researcher bias might lead to such results, I used Terpstra's (1981) evaluation scheme. Based on this test, poor methodology did not seem responsible for the conclusions on the value of formal planning.

Foster suggests that Terpstra's test was not valid because the studies were not experimental. I disagree. The possibility exists to do experimental work. Van de Ven (1980) approaches this ideal. Furthermore five of the six Terpstra scale items are relevant to quasiexperimental or non-experimental research. There may, however, be other reasons to challenge the validity of these scales.

While I accepted the validity of the scales in my original study, 1 reported some difficulty in applying the scale. This was surprising inasmuch as the scale seems simple and Terpstra had reported 100 per cent interrater reliability for its use in his study on organizational development. In any event, the reliability of the scales was open to question.

In my opinion, Foster is correct in challenging the Terpstra test, but for other reasons. Recent research has cast doubt on the use of Terpstra's scale. Bullock and Svyantek (1985) attempted to replicate Terpstra's study. Unable to obtain information from Terpstra, they applied his process to the literature that he claimed to have used. They concluded, in contrast to Terpstra, that there was no evidence of researcher bias in these studies. Part of the problem, it seems, was the difficulty in obtaining reliable ratings with the scale. (Interestingly, in an as yet unpublished rebuttal, Terpstra (1985) tried to replicate the Bullock and Svyantek extension, but he was unable to obtain the necessary information from them.)

Recent research allows us to approach researcher bias from a different viewpoint. If such a bias exists, it should show up in what is accepted for publication. Typically, the papers accepted are more likely to support current beliefs than are the rejected studies. (For a review of the research leading to this conclusion, see Armstrong (1982). Shrader, Taylor and Dalton (1984) studied the value of planning by including both published and unpublished studies in the meta-analysis. Of the six unpublished studies they found, four favored formal planning and none favored informal planning. These results are consistent with their published studies: seven of nine favored formal planning and none were unfavorable. I did not have access to these studies, but Shrader used a different and much broader definition of studies than used in Armstrong (1982a).

While on the subject, it is possible that we (Armstrong, Makridakis and Hoffman) were biased in our coding. To guard against this in the original study, $t$ contacted the authors of the studies and asked each of them to verify our codings of their paper. As a further check, I compared our ratings on the value of formal planning with those made by Shrader, et al. The ratings were in agreement for 9 of the 11 comparisons that overlapped. On the two ratings that differed, we rated formal planning as superior, while Shrader coded them as ties. In a similar test, ratings fromRhyne (1985) were found to be identical to our ratings in all 8 studies that were common. Overall then, the ratings appear to be reliable.

The search for papers is another potential source of bias. Inasmuch as different terms are used by different disciplines when studying planning, it is likely that much relevant research was omitted by my original review. My literature review had followed the standard procedures by using indexes and by obtaining references from key papers. In addition, I sent copies of the paper to all authors of empirical studies to determine whether they knew of any studies that had been overlooked. Since publication, only two studies have come to my attention that meet the original criteria as an empirical study relating the formal planning process to success. One of these, Sapp and Seiler 
(1981) favored the use of formal planning, while the other, Robinson and Pearce (1983) found no difference. The updated boxscore, then, is 11 studies favoring formal planning, 8 showing no difference, and 2 favoring informal planning.

The evidence does not point to researcher bias as an explanation. Still, I agree with Foster that this issue is far from resolved. We need research that is conducted with considerably more care. Studies should describe the aspects of planning, the situation, and the outcomes for the complete system. Admittedly, this is difficult and expensive to do when using field studies. An alternative is to use realistic case studies that have known outcomes (although not known to the subjects). The subjects can then be split into experimental and control groups. The experimentals would be trained in the formal planning process and their subsequent performance would be compared to that of the controls. This proposal is discussed in more detail in Armstrong and Reibstein (1985).

The cross-sectional field studies with ill-defined descriptions of the planning process will add little to what is already known. Carefully designed studies are needed if we hope to find definitive answers on how to plan, when to plan and what to expect.

\section{References}

Armstrong, J. S (1982a), "The value of formal planning for strategic decisions: Review of empirical research," Strategic Management Journal, 3, 197-211.

Armstrong, J. S. (1982b), "Research on scientific journals: Implications for editors and authors," Journal of Forecasting, 1, 83-104.

Armstrong, J. S. and David J. Reibstein (1985), "Evidence on the value of strategic planning in marketing: How much planning should a marketing planner plan?” in H. Thomas and D. Gardner, Strategic Marketing and Management. Chichester: Wiley, 73-87.

Bullock, R. J. and D. J. Svyantek (1985), “Analyzing meta-analysis: Potential problems, an unsuccessful replication, and evaluation criteria," Journal of Applied Psychology, 70, 108-115.

Rhyne, Lawrence C. (1985), “The relationship of strategic planning to financial performance,” Strategic Management Journal, 4, 319-337.

Robinson, R. B., Jr. and J. A. Pearce, II (1983), “The impact of formalized strategic planning on financial performance in small organizations,: Strategic Management Journal, 4, 197-207.

Sapp. R. W. and R. E. Seiler (1981), "The relationship between long-range planning and financial performance of U.S. commercial banks," Managerial Planning, 29, 32-36.

Shrader, C. B., L. Taylor, and D. R. Dalton (1984), "Strategic planning and organizational performance: A critical appraisal," Journal of Management, 10, 149-171.

Terpstra, D. E. (1981), "Relationship between methodological rigor and reported outcomes in organization development evaluation research," Journal of Applied Research, 66, 541-543.

Terpstra, D. E. (1985), “Analyzing unsucces sful replications: potential problems and the role of investigator bias in organization development evaluation research'," Unpublished manuscript, Department of Business, University of Idaho, Moscow, Idaho.

Van de Ven, A. H. (1980), "Problem solving, planning, and innovation, Part I . Test of the program planning model," Human Relations, 33, 711-740. 